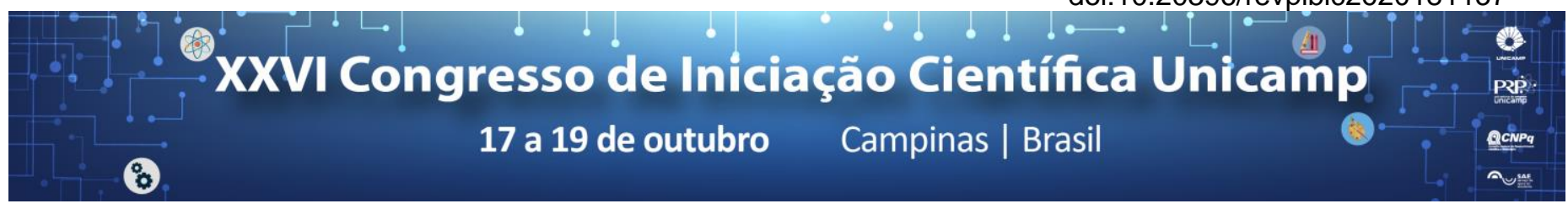

\title{
DIREITO DE PATRONATO ENTRE A MANUTENÇÃO E A REVOGAÇÃO DA LIBERDADE
}

\author{
Pedro Henrique Gericó Speri, Prof. Dr. Aldair Carlos Rodrigues
}

\begin{abstract}
Resumo
Partindo da leitura de centenas de cartas de alforria e amparando-se em bibliografia pertinente, o projeto buscou compreender um elemento presente na sociedade brasileira colonial escravista: o direito do patronato, enfocando suas expressões não apenas na obtenção da liberdade, mas também nas disputas por sua manutenção e revogação. $O$ enfoque dado foi sobre a atual cidade de Mariana (MG) no segundo quartel do século XVIII, período em que o contingente de escravizados da chamada Costa da Mina e de seus descendentes já era expressiva, sendo que este grupo foi o que predominou entre os sujeitos que obtiveram alforria.
\end{abstract}

\section{Palavras-chave:}

Alforrias, direito do patronato, diáspora africana

\section{Introdução}

A prática das manumissões foi frequente na sociedade colonial brasileira, não se restringindo a determinados períodos e localidades específicas. Elas poderiam ser obtidas de diferentes formas: compradas, pagas com outros cativos, quartadas ou concedidas. Um elemento em comum envolvido nessas possibilidades eram as relações de patronato, uma das heranças do direito romano que compunham as relações entre senhores / escravizados, senhores / alforriados e outros sujeitos da hierarquia social luso-brasileira. A lógica do patronato permeava, entre outros pontos, as esmolas deixadas pelos libertos a seus antigos senhores ou mesmo a adoção dos sobrenomes dos antigos senhores pelos alforriados. Além disso, ela era recorrentemente acionada por proprietários com o intuito de retornar seu domínio legal sobre alforriados que, por exemplo, injuriassem publicamente seus antigos senhores ou não os amparassem em necessidades. Os litígios poderiam ser levados ao campo jurídico através das chamadas "ações de liberdade" ou "reclamações de liberdade" ou "ações de manutenção de liberdade". De um lado, os senhores e patronos intencionavam a reescravização; do outro, libertos e seus representantes lutavam pela manutenção ou restauração de suas condições de libertos.

\section{Resultados e Discussão}

Considerando as alforrias que compõem o banco de dados ao qual este projeto esteve inserido, houve uma predominância de mulheres entre os sujeitos que alcançaram a manumissão, apesar de terem sido minoria no conjunto da população escrava. De modo geral, a historiografia considerou como hipóteses para essa ocorrência o preço inferior das escravas, o grau de afetividade construído entre elas e seus senhores ou mesmo a solidariedade entre as famílias escravizadas, preferindo alforriar as mulheres para preservar os descendentes da escravidão. No entanto, na região e período abordados no projeto, as pretas minas e suas crianças se sobressaíram na conquista da liberdade, fazendo com que apenas as hipóteses acima não sejam suficientes para uma análise mais apurada da predominância desse grupo nas cartas de liberdade. Sendo assim, consideramos ser necessário levar em conta a dimensão diaspórica da formação e trajetória dessas mulheres e suas famílias, aspectos que contribuíram de forma direta em sua predominância, permitindo compreensões além das tradicionalmente eurocêntricas.

\section{Conclusões}

Constatamos, a partir da análise das alforrias e do estudo relacionado às ações de liberdade, que o direito de patronato se fazia presente nas relações anteriores e posteriores à conquista da liberdade, entre senhores / escravizados e senhores / alforriados.

Ao final deste projeto, uma questão nos surgiu e permaneceu em aberto: $O$ direito do patronato, um elemento romano na escravidão luso-atlântica, influiu nas relações entre pretas minas forras e suas cativas e libertas, ou seja, sem o envolvimento direto de senhores brancos? Cremos que sim, mas com contornos diferentes. Por um lado, constituído pelo aparato cultural trazido e (re)construído por essas mulheres africanas; por outro, pelas instituições e práticas portuguesas exercidas na colônia.

\section{Agradecimentos}

Agradeço a bolsa de iniciação científica que permitiu o desenvolvimento desta pesquisa, a qual se inseriu num projeto mais amplo desenvolvido pelo orientador: "A diáspora africana por uma perspectiva étnica: os etnônimos entre o interior da América portuguesa e o interior da Baía do Benin (século XVIII)" - AUXPE (0382/2016); do FAEPEX Convênio 3201/16. Agradeço também à orientação e paciência do professor Aldair Rodrigues, aos colegas bolsistas do banco de dados e ao grupo de estudos dedicado à diáspora africana no interior do Brasil colonial.

\footnotetext{
${ }^{1}$ DIÓRIO, R. R. Os libertos e a construção da cidadania em Mariana, 1780 1840. 2013. Tese (Doutorado em História Social) - Faculdade de Filosofia, Letras e Ciências Humanas, Universidade de São Paulo, São Paulo.

${ }^{2}$ GONÇALVES, A. L. As margens da liberdade: estudo sobre a prática de alforrias em Minas colonial e provincial. Belo Horizonte: Fino Traço, 2011.

${ }^{3}$ PATTERSON, O. Escravidão e morte social: Um estudo comparative. São Paulo: Editora da Universidade de São Paulo, 2008.

${ }^{4}$ PINHEIRO, F. D. Em defesa da liberdade: libertos e livres de cor nos tribunais do Antigo Regime português (Mariana e Lisboa, 1720-1819). Tese (Doutorado em História Social) - Instituto de Filosofia e Ciências Humanas, Campinas.

5 SOARES, M. de S. A remissão do cativeiro: a dádiva da alforria e o governo dos escravos nos Campos dos Goitacases, c. $1750-c$. 1830. Rio de Janeiro: Apicuri, 2009.
} 